\title{
Spatiotemporal signals and palaeoenvironments of endemic molluscan assemblages in the marine system of the Sarmatian Paratethys
}

Susanne Lukeneder, Martin Zuschin, Mathias Harzhauser, and Oleg Mandic Acta Palaeontologica Polonica 56 (4), 2011: 767-784 doi: http://dx.doi.org/10.4202/app.2010.0046

The present study is the first quantitative comparison of Sarmatian mollusc assemblages from the Central and Eastern Paratethys seas. The assemblages (47,840 shells, 32 samples, 84 species) derive from eight Middle and Upper Miocene localities covering an interval from 12.7-11.0 Ma, when a highly endemic mollusc fauna flourished in the entire Paratethys. Cluster analysis of samples yields two major clusters: one composed of late Sarmatian (Bessarabian) collections and the other composed of early Sarmatian (Volhynian) collections. The Volhynian cluster includes two subclusters: the first reflects a strong stratigraphic signal because it combines samples from the Mohrensternia Zone of the Vienna Basin and the western Ukraine. The second combines samples from the Upper Ervilia Zone of the Vienna Basin with samples from the Mohrensternia Zone of the Vienna Basin and Romania. Cluster analysis of species indicates that the sample clusters represent different palaeoenvironments with distinct molluscan assemblages: The Volhynian well-agitated shore is characterized by the Granulolabium-Venerupis-Ervilia biofacies, the Volhynian muddy foreshore by the Granulolabium-Mohrensternia-Ervilia biofacies, and the Bessarabian shallow to medium deep sublittoral by the Hydrobia-Venerupis-Pseudamnicola biofacies. Although not all biozones and regions of the Sarmatian Sea are covered, we suggest that these biofacies cover a wide range of possible assemblage compositions of Sarmatian nearshore and shallow-water assemblages.

Key words: Bivalvia, Gastropoda, endemism, Volhynian, Bessarabian, Miocene, Paratethys Sea.

Susanne Lukeneder [Susanne.Lukeneder@nhm-wien.ac.at] and Martin Zuschin [ martin.zuschin@univie.ac.at], University of Vienna, Department of Palaeontology, Althanstrasse 14, A-1090 Vienna, Austria; Mathias Harzhauser [mathias.harzhauser@nhm-wien.ac.at], and Oleg Mandic [oleg.mandic@nhm-wien.ac.at] Natural History Museum Vienna, Geological-Palaeontological Department, Burgring 7, A-1010 Vienna, Austria. 
This is an open-access article distributed under the terms of the Creative Commons

Attribution License (for details please see creativecommons.org), which permits unrestricted use, distribution, and reproduction in any medium, provided the original author and source are credited.

Forif Full text $(1,014.6 \mathrm{kB})$ 